\title{
Notes
}

\section{Rule 11 and Collateral Attack on Guilty Pleas}

The vast majority of convictions in the federal criminal system occurs when a defendant pleads guilty. ${ }^{1}$ Pleas of guilty are entered at a hearing governed by Rule 11 of the Federal Rules of Criminal Procedure. In 1975, Congress substantially amended Rule 11 to expand that hearing and thus provide a more comprehensive record of all matters bearing on the validity of the plea. ${ }^{2}$ Such a record, it was

1. In 1974, approximately $84 \%$ of the 36,230 federal convictions were obtained by pleas of guilty or nolo contendere. [1974] AD. OF. OF THE U.S. CourTs ANN. REP. 470.

2. Federal Rules of Criminal Procedure Amendments Act of 1975, Pub. L. 94-64, 89 Stat. 370 (1975). Rule 11 reads in part:

(c) Advice to Defendant. Before accepting a plea of guilty or nolo contendere the court must address the defendant personally in open court and inform him of, and determine that he understands, the following:

(l) the nature of the charge to which the plea is offered, the mandatory minimum penalty provided by law, if any, and the maximum possible penalty provided by law; and

....

(3) that he has the right to plead not guilty or to persist in that plea if it has already been made, and that he has the right to be tried by a jury and at that trial has the right to the assistance of counsel, the right to confront and cross-examine witnesses against him, and the right not to be compelled to incriminate himself; and

(d) Insuring That the Plea is Voluntary. The court shall not accept a plea of guilty or nolo contendere without first, by addressing the defendant personally in open court, determining that the plea is voluntary and not the result of force or threats or of promises apart from a plea agreement. The court shall also inquire as to whether the defendant's willingness to plead guilty or nolo contendere results from prior discussions between the attorney for the government and the defendant or his attorney.

(e) Plea Agreement Procedure.

(I) In General. The attorney for the government and the attorney for the defendant or the defendant when acting pro se may engage in discussions with a view toward reaching an agreement that, upon the entering of a plea of guilty or nolo contendere to a charged offense or to a lesser or related offense, the attorney for the government will do any of the following:

(A) move for dismissal of other charges; or

(B) make a recommendation, or agree not to oppose the defendant's request, for a particular sentence, with the understanding that such recommendation or request shall not be binding upon the court; or

(C) agree that a specific sentence is the appropriate disposition of the case. The court shall not participate in any such discussions.

(2) Notice of Such Agreement. If a plea agreement has been reached by the parties, the.court shall, on the record, require the disclosure of the agreement in open court or, on a showing of good cause, in camera, at the time the plea is offered. Thereupon the court may accept or reject the agreement, or may defer 
hoped, would assist federal courts in reviewing the great number of post conviction attacks made on guilty pleas. ${ }^{3}$

This Note will assess the utility of the Rule 11 record in disposing of post conviction challenges. Broadly speaking, such challenges can be based either upon the defendant's alleged misunderstanding at the time of pleading guilty or upon events occurring outside the guilty plea hearing that may affect the validity of the plea. ${ }^{4}$ In the former case, the Rule 11 record may be dispositive of the post conviction attack. In the latter case, the record can be far less helpful, for the defendant may easily impeach the findings made at the Rule 11 hearing as to the voluntariness of his plea or the nonexistence of secret plea bargaining. The defendant's failure to raise claims about these matters at the hearing, furthermore, cannot properly be interpreted as a waiver of such claims. For these reasons, the Note concludes that the Rule 11 record will not foreclose post conviction challenges containing credible allegations of government coercion or secret promises.

Perhaps cognizant of the limited utility of the Rule 11 record, some federal courts concerned with finality for criminal convictions have established evidentiary and other barriers to attacks on guilty pleas. Also, recently adopted rules of procedure for post conviction motions ${ }^{5}$ attempt to offer a means for disposing of such motions without a full judicial hearing, in part by expanding the written record on which they may be considered. The Note argues that these techniques will fail to eliminate profitless hearings on the validity of guilty pleas or

its decision as to the acceptance or rejection until there has been an opportunity to consider the presentence report.

(3) Acceptance of a Plea Agreement. If the court accepts the plea agreement, the court shall inform the defendant that it will embody in the judgment and sentence the disposition provided for in the plea agreement.

(4) Rejection of a Plea Agreement. If the court rejects the plea agreement, the court shall, on the record, inform the parties of this fact, advise the defendant personally in open court or, on a showing of good cause, in camera, that the court is not bound by the plea agreement, afford the defendant the opportunity to then withdraw his plea, and advise the defendant that if he persists in his guilty plea or plea of nolo contendere the disposition of the case may be less favorable to the defendant than that contemplated by the plea agreement.

3. See p. 1405 infra.

4. Another important category of claims alleges ineffective assistance of counsel. E.g., Dukes v. Warden, 406 U.S. 250 (1972) (claim of conflict of interest by counsel); see Green, Ward \& Arcuri, Plea Bargaining: Fairness and Inadequacy of Representation, 7 Colum. Human Rights L. Rev. 495 (1975) (collecting cases). Since Rule 11 makes no attempt to insulate guilty pleas against attacks of this sort, consideration of the problems they create is outside the scope of this Note.

5. Rules Governing Section 2255 Proceedings for the United States District Courts (effective Feb. 1, 1977), reprinted in 28 U.S.C.A. foll. $\$ 2255$, at 104-22 (West Supp. 1977) [hereinafter cited as SECTION 2255 RuLEs]. 
will mechanically deny hearings regardless of the underlying merits of the challenge. The Note concludes that post conviction attacks on guilty pleas need to be heard despite the admitted costs, both in time and in expense, that such hearings entail.

\section{Rule 11 and Pleas of Guilty}

The Constitution requires that guilty pleas be intelligent and voluntary. ${ }^{\circ}$ To be intelligent, a plea must be made by a mentally competent defendant ${ }^{7}$ who understands both the charges against him ${ }^{8}$ and the consequences of his plea. ${ }^{9}$ To be voluntary, a plea must be free of threats or other coercion that would impermissibly distort the

6. As amended in 1966 , Rule 11 required a judge accepting a guilty plea to determine that the plea was made "voluntarily with understanding of the nature of the charge and the consequences of the plea." Fed. R. Crim. P. 11, 383 U.S. 1087, 1097 (1966). These requirements derive from the fact that a guilty plea embodies a waiver of trial rights. See note 45 infra. These rights include the privilege against self-incrimination, the right to trial by jury and the right to confront adverse witnesses. See Boykin v. Alabama, 395 U.S. 238, 243 (1969); McCarthy v. United States, 394 U.S. 459, 466 (1969). Boykin required, as a matter of constitutional law, that "the prerequisites of a valid waiver" of these rights be spread on the record before a guilty plea is accepted. 395 U.S. at 242.

7. Sanders v. United States, 373 U.S. 1, 19-20 (1963); Malinauskas v. United States, 505 F.2d 649, 652-54 (5th Cir. 1974); Sieling v. Eyman, 478 F.2d 211, 214-15 (9th Cir. 1973). In defining the level of competence needed to stand trial, the Supreme Court has stated that a defendant must have "sufficient present ability to consult with his lawyer with a reasonable degree of rational understanding [and] a rational as well as factual understanding of the proceedings against him." Duskey v. United States, 362 U.S. 402,402 (1960) (per curiam) (quoting from and adopting position of Solicitor General). This standard is usually applied to defendants who plead guilty. Sce Malinauskas v. United States, 505 F.2d 649, 653-54 (5th Cir. 1974); United States v. Harlan, 480 F.2d 515, 517 (6th Cir.), cert. denied, 414 U.S. 1006 (1973). But see Sieling v. Eyman, 478 F.2d 211, 21415 (9th Cir. 1973) (applying a higher standard of competence to guilty plea defendants).

8. See Henderson v. Morgan, 426 U.S. 637, 644-45 \& n.13 (1976); McCarthy v. United States, 394 U.S. 459, 466.67 (1969). Cf. Belgarde v. Turner, 421 F.2d 1395, 1396 (10th Cir. 1970) (failure to explain difference between second and third degree burglary voids plea). This requirement ensures that the defendant understands the elements that the state must prove to prevail at trial, i.e., that he possesses "an understanding of the law in relation to the facts." McCarthy v. United States, 394 U.S. at 466 (footnote omitted). See ABA Standards Relating to Pleas of Guilty $\$ 1.4$, Commentary at 26 (Approved Draft, 1968) [hereinafter cited as ABA Guil.tY PleA StANDARds].

9. See Brady v. United States, 397 U.S. 742, 748 (1970); United States v. Blair, 470 F.2d 331, 339-40 (5th Cir. 1972), cert. denied, 411 U.S. 908 (1973). See generally J. Bond, Plei Bargaining and Guilty Pleas, 138-54 (1975).

Before 1975, Rule 11 required the court to ascertain that the defendant understood the "consequences of the plea." Fed. R. Crim. P. 11, 383 U.S. 1087, 1097 (1966). The 1975 Amendments dropped this language and substituted a requirement that the defendant be informed of "the mandatory minimum penalty provided by law, if any, and the maximum possible penalty provided by law." FED. R. CRIM. P. 11(c)(1). The 1966 language stimulated considerable litigation as to what "consequences" were sufficiently serious to warrant inclusion in the judicial warnings. The 1975 substitute no doubt will do the same. See, e.g., United States v. Watson, 548 F.2d 1058, 1060-61 (D.C. Cir. 1977); United States v. Journet, 544 F.2d 633, 635-37 (2d Cir. 1976). 


\section{defendant's choice. ${ }^{10}$ If these constitutional requisites are not met, a guilty plea may be set aside in a post conviction attack. ${ }^{11}$}

10. The most complete statement of the standard used to test the voluntariness of a guilty plea is found in Brady v. United States, 397 U.S. 742 (1970):

" [A] plea of guilty entered by one fully aware of the direct consequences . . . must stand unless induced by threats (or promises to discontinue improper harassment), misrepresentation (including unfulfilled or unfulfillable promises), or perhaps by promises that are by their nature improper as having no proper relationship to the prosecutor's business (e.g., bribes)." "

Id. at 755 (quoting with approval Shelton v. United States, 246 F.2d 571, 572 n.2 (5th Cir. 1957), rev'd on other grounds, 356 U.S. 26 (1958) (quoting Shelton v. United States, 242 F.2d 101, 115 (5th Cir. 1957) (Tuttle, J., dissenting))). This standard proscribes two different sorts of coercion. In some cases, government conduct (e.g., a prolonged beating) will so overbear the defendant's will as to make him incapable of independent choice. In other cases, although the defendant's ability to choose remains unimpaired, a plea will be found involuntary if induced by unfair or illegal government tactics (e.g., a threat to impose an illegal sentence). See Parker v. North Carolina, 397 U.S. 799, 801-02 (1970) (Brennan, J., dissenting).

In assessing coercion, courts apply different rules to different legal actors. Prosecutors are given considerable latitude to "persuade" defendants to plead guilty. Essentially, they may threaten defendants with any consequences within the scope of lawful prosecutorial powers. E.g., Meyer v. United States, 424 F.2d 1181, 1188 (8th Cir.), cert. denied, 400 U.S. $853(1970)$ (threat to prosecute when facts warranted prosecution not coercive); Ford $v$. United States, 418 F.2d 855, 859 (8th Cir. 1969) (same). But see Hayes v. Cowan, 547 F.2d 42, 44 (6th Cir. 1976), cert. granted, 97 S. Ct. 2672 (1977) (prosecutor may not threaten to add to indictment when defendant refuses to plead guilty). But if prosecutors threaten defendants with physical abuse or illegal trial tactics, the plea is held involuntary. See Broxson v. Wainwright, 477 F.2d 397, 398-99 (5th Cir. 1973) (threat to shoot and kill defendant; threat of sexual harm to wife and sister); Lassiter v. Turner, 423 F.2d 897, 900 (4th Cir.), cert. denied, 400 U.S. 852 (1970) (threat to revive charge barred by speedy trial rights). Similar rules are applied to police and federal agents. See Fontaine v. United States, 411 U.S. 213, 214-15 (1973) (physical abuse and prolonged interrogation by police); Waley v. Johnston, 316 U.S. 101, 102-04 (1942) (threat by F.B.I. agent to manufacture false evidence).

Stricter rules govern judicial behavior. See Notes of the Advisory Committee on 1975 Amendments to Rules, FED. R. CRIM. P. 11, reprinted in 18 U.S.C. app. at 1304.05 (Supp. $V$ 1975) [hereinafter cited as 1975 Advisory Committee Notes]; Ferguson, The Role of the Judge in Plea Bargaining, 15 CRIM. L.Q. 26, $40-43$ (1971) (citing English and American cases); Gallagher, Judicial Participation in Plea Bargaining; $A$ Search for New Standards, 9 Harv. C.R.-C.L. L. REv. 29, 38-45 (1974). For example, a judicial threat to sentence a defendant harshly if he does not plead guilty will invalidate a plea whether or not the sentence is within the judge's legal powers. See Matthews v. United States, 533 F.2d 900, 903 (5th Cir. 1976), cert. denied, 97 S. Ct. 1156 (1977); United States v. Tateo, 214 F. Supp. 560, 567 (S.D.N.Y. 1963). Rule 11 now forbids judges to participate in discussions between prosecutor and defense counsel leading up to a plea agreement. FED. R. CRIM. $P$. 11(c)(1). See United States v. Werker, 535 F.2d 198, 201 (2d Cir. 1976) (Rule 11 bars judge from promising specific sentence prior to entry of guilty plea).

Defense attorneys may also engage in coercive conduct. For example, a plea made in reliance on false statements by defense counsel that a plea bargain has been arranged with the government is deemed involuntary. See United States v. Simpson, 436 F.2d 162, 164 (D.C. Cir. 1970); United States v. Pallotta, 433 F.2d 594, 595 (Ist Cir. 1970). Defense attorneys are also forbidden to pressure defendants into pleading guilty by threatening to withdraw from the case. See Edmonds v. Lewis, 546 F.2d 566, 569 (4th Cir. 1976) (Butzner, J., dissenting); Coleman v. Wilson, 401 F.2d 536 (9th Cir. 1968), cert. denied, 393 U.S. 1065 (1969).

11. Defendants in federal court have two avenues to post conviction relief: the motion to withdraw a guilty plea, FED. R. CRrM. P. 32(d), and the motion to vacate or correct sentence, 28 U.S.C. $\$ 2255(1970)$. The two procedures offer broadly similar relief. 
In recent years, a series of steps has been taken to improve the procedures for taking guilty pleas and thus to enhance the finality of convictions based on them. In 1966, Rule 11 was amended to expand the scope of the plea hearing in order to produce a better record. ${ }^{12}$ District judges were instructed to ascertain the intelligent (that is, knowing) and voluntary character of the plea by addressing the defendant personally, rather than by relying on the representations of defense counsel.13 The Amendments also required that a "factual basis" for the plea be established, either by admissions of the defendant or by evidence in the hands of the government. ${ }^{14}$ It was hoped that the 1966 Amendments would "prevent post-conviction attacks," which previously had "required extensive hearings." "15

The effectiveness of the 1966 Amendments initially was hampered by the courts' failure to insist that the new requirements be strictly observed. Many appellate courts permitted guilty pleas to stand even though district judges had not fully complied with Rule $11 .{ }^{16}$ Yet in

Although the motion to withdraw a guilty plea affords somewhat greater discretion to the district judge, see Meyer v. United States, 424 F.2d 1181, 1190 (8th Cir.), cert. denied, 400 U.S. 853 (1970), a violation of defendant's constitutional rights in accepting a plea mandates relief regardless of the type of motion made. See United States v. Crusco, 536 F.2d 21, 26 (3d Cir. 1976). See generally 8A Moore's Federal Practice f 32.07[4] (2d ed. 1976). This Note will focus primarily on the motion to vacate sentence, usually called a "\$ 2255 motion."

12. Fed. R. Crim. P. 11, 383 U.S. 1087, 1097 (1966). See Notes of Advisory Committee on 1966 Amendments to Rules, Fed. R. Crim. P. 11, reprinted in 18 U.S.C. app. at 4489-90 (1970) [hereinafter cited as 1966 Advisory Committee Note]. For commentary on the 1966 Amendments, see Hoffman, What Next in Federal Criminal Rules?, 21 WASH. \& LEE L. REv, 1, 8-11 (1964); Rezneck, The New Federal Rules of Criminal Procedure, 54 Geo. L.J. 1276, 1309.10 (1966).

13. See 1966 Advisory Committee Note, supra note 12, at 4489; Hoffman, supra note 12, at 10. Before the 1966 Amendments, judges had relied on statements by defense counsel. See, e.g., Nunley v. United States, 294 F.2d 579 (10th Cir. 196I), cert. denied, 368 U.S. 991 (1962); United States v. Von der Heide, 169 F. Supp. 560, 566 (D.D.C. 1959) ("The Court may always rely on representations of counsel.") Cf. Comment, 18 S.C.L. REv. 668, 673-74 (1966) (disapproving of judicial reliance on representations of defense counsel).

14. FED. R. Crim. P. 11(f); 1966 Advisory Committee Note, supra note 12, at 4489-90. Because the "factual basis" can be satisfied by defendant's admission that he committed the crime, problems arise only when defendant refuses to admit guilt expressly but nevertheless wishes to plead guilty. In these circumstances, courts must examine the sufficiency of the government's evidence. See North Carolina v. Alford, 400 U.S. 25, 38 n.10 (1970).

15. Hoffman, supra note 12 , at 11 .

16. See Kennedy v. United States, 397 F.2d 16 (6th Gir. 1968), cert. denied, 394 U.S. 1018 (1969) (district judge's noncompliance with Rule 11 not per se a basis for setting aside a guilty plea); Halliday v. United States, 380 F.2d 270, 272 (1st Cir. 1967) (same); Stephens v. United States, 37o F.2d 23 (10th Cir.), cert. denied, 389 U.S. 881 (1967); Brokaw v. United States, 368 F.2d 508 (4th Cir. 1966), cert. denied, 386 U.S. 996 (1967). But see Heiden v. United States, 353 F.2d 53 (9th Cir. 1965) (failure to comply with Rule 11 is ground to set aside the plea). These courts did provide defendants with an evidentiary hearing on the intelligence of their guilty plea when the requirements of Rule 11 had not been strictly satisfied. 
1969, McCarthy v. United States ${ }^{17}$ made full compliance with Rule 11 mandatory. Recognizing that the Rule was designed to develop a complete record on the validity of a guilty plea at the time it was entered, the Supreme Court held that defendants who pled guilty at a defective hearing must be allowed to plead again. ${ }^{18}$ The Court emphasized that strict compliance with Rule 11 would deter or at least facilitate the disposition of "the numerous and often frivolous post-conviction attacks" on guilty pleas. ${ }^{19}$

In 1971, Santobello v. New York ${ }^{20}$ cast doubt on the viability of existing Rule 11 procedures when it established a new constitutional basis for attacking guilty pleas. Santobello confronted the prevalent but theretofore officially unacknowledged practice of plea bargaining. ${ }^{21}$ The Court explicitly recognized the propriety of plea bargaining, but held that government promises which were "part of the inducement or consideration" for a guilty plea had to be fully performed if the plea were to stand. ${ }^{22}$ After Santobello it was no longer sufficient

17. 394 U.S. 459 (1969).

18. Id. at 468-69. Recently, some courts have questioned whether mere noncompliance with Rule 11 without a showing of prejudice should be grounds for relief in a $\$ 2255$ motion. Such courts limit $M c$ Carthy to review by direct appeal or by motion to withdraw a guilty plea. See Del V'ecchio v. United States, 556 F.2d 106 (2d Cir. 1977); United States v. Watson, 548 F.2d 1058, 1062-63 (D.C. Cir. 1977); McRae v. United States, 540 F.2d 943, 945.46 (8th Cir. 1976); Gates v. United States, 515 F.2d 73, 76-77 (7th Cir. 1975).

19. 394 U.S. at 465 .

20. 404 U.S. 257 (1971).

21. On the prevalence of plea bargaining, see PRESIDENT's CoMmission on LAW ENFORCEMENT AND AdMINistration of JUSTICE, TASK ForCE Report: THE CouRTs 9 (1967) [hereinafter cited as TASK Force REPORT]; Alschuler, The Prosecutor's Role in Plea Bargaining, 36 U. CHr. L. REv. 50, $50-51$ (1968); Newman \& NeMroyer, Issues of Propriely in Negotiated Justice, 47 DEN. L.J. 367, 369 (1970). The frequency of plea bargaining is known to vary from jurisdiction to jurisdiction; it is most prevalent where the caseload is heaviest. See Proposed Amendments to Federal Rules of Criminal Procedure: Hearings Before the Subcomm. on Criminal Justice of the House Comm. on the Judiciary, 93d Cong., 2d Sess. 20-22 (1974) (statement of Judge Webster) [hereinafter cited as House Hearings I]; Finkelstein, A Statistical Analysis of Guilty Plea Practices in the Federal Courts, 89 Harv. L. REv. 293, 307 (1975). In some courts, there is little or no plea bargaining; in others, certain types of plea bargains are not used. In the Southern District of New York, for example, "[t]\}here are no plea agreements in the sense of an agreement on a recommendation of a particular sentence. And the U.S. attorney will not participate in such discussions, and the judges do not accept them." House Hearings I, supra, at 24 (Judge Lumbard). See id. at 20 (statement of Judge Webster) (no plea bargaining in Eastern District of Missouri except agreements to drop one or more of multiple charges). But see Hoffman, Plea Bargaining and the Role of the Judge, 53 F.R.D. 499, 502.03 (1971) (every federal judge has "tacitly approved" concessions that are "tantamount to plea bargaining").

22. 404 U.S. at 262. As explained by the Court in Santobello, the legitimacy of plea bargaining "presuppose[s] fairness" in the agreement process. Id. at 261 . Once a guilty plea that rests on a government promise has been made, it is "reasonably due" to the defendant that "such promise must be fulfilled." Id. at 262 . A concurring opinion referred to " "an outraged sense of fairness" " as the basis for this rule. Id. at 260 (Douglas, J., concurring) (quoting D. Newman, Convicrion 36 (1966)).

Because the Santobello majority did not explicitly state that its holding was constitu- 
to scrutinize a plea's intelligence and voluntariness: ${ }^{23}$ if a defendant's constitutional rights were to be enforced, the promises made had to be identified and recorded. Because plea bargaining had traditionally been carried on in secret and had routinely been concealed at Rule 11 hearings, ${ }^{2+}$ some means of bringing plea bargain promises to light was needed. ${ }^{25}$

tional, see id. at 266-67 (Douglas, J., concurring), some observers interpreted it as a nonconstitutional rule. Comment, Plea Bargaining Mishaps-The Possibility of Collaterally Attacking the Restltant Plea of Guilty, 65 J. Crim. L. \& Criminology 170, 175 (1975) [hereinafter cited as Comment, Plea Bargaining Mishaps]. Yet Santobello originated in a state court. The Supreme Court has no supervisory power over state courts and there was no other federal question in the case. Unless the Court was making a constitutional ruling, it had no right to decide the case at all. Later courts have treated Santobello as establishing a constitutional rule. See Lebosky v. Saxbe, 508 F.2d 1047, 1050 (5th Gir. 1975); Paradiso v. United States, 482 F.2d 409, 411 (3rd Cir. 1973).

Two remedies exist for a broken plea bargain: defendant may withdraw his plea or have the promise enforced. See Santobello v. New York, 404 U.S. 257, 263 (1971). The majority in Santobello left the choice of remedy to the discretion of the state court. Justice Douglas, concurring, suggested that weight be given to the defendant's preference, and three dissenting Justices would have made the defendant's preference dispositive. Santobello thus established no firm guidelines for determining remedies. At present, most courts allow defendant to withdraw a guilty plea if he shows a broken promise. See Note, The Legitimation of Plea Bargaining: Remedies for Broken Promises, 11 AM. CRIM. L. REv. 771, 792-94 (1973) (withdrawal of plea is "most common" form of relicf granted).

23. Some observers noted that Santobello had imported into the criminal law many of the vexing problems that surround enforcement of commercial contracts. See Paradiso v. United States, 482 F.2d 409, 411 (3rd Cir. 1973) (“Santobello . . . generated further litigation over what constitutes a promise, whether any promise had been made, and the effect of advice or assurance given by the defendant's own counsel.") $C f$. Blackledge v. Allison, 97 S. Ct. 1621, 1630 n.6 (1977) (analogy to parole evidence rule). Ascertaining the conditions under which assurances by government officials will achieve the status of enforceable promises is a common problem. See, e.g., United States v. Hammerman, 528 F.2d 326, 330-31 (4th Cir. 1975) (prosecutor's prediction "likely to inculcate belief and reliance" is enforceable promisc); United States ex rel. Culbreath v. Rundle, 466 F.2d 730, 735 (3rd Cir. 1972) (prosccutor's recommendation to court must be granted, or plea must be allowed to be withdrawn); United States v. Frontero, 452 F.2d 406, 411 (5th Cir. 1971) (trial court's prediction of probable sentence not an enforceable promise). Another problem is the determination of which government agents can legally bind the government. See United States v. Huffman, 490 F.2d 412, 414 (8th Cir. 1973), cert. denied, 416 U.S. 988 (1974) (probation officer); Palermo v. Rockefeller, 323 F. Supp. 478, 484-85 (S.D. N.Y. 1971) (parole board); Comment, Plea Bargaining Mishaps, supra note 22, at 176-77 (police).

24. Plea bargaining has long been recognized as an "informal, invisible" process. TASK FORCE REPORT, supra note 21, at 9. The fact that bargaining had taken place was concealcd because of widespread doubts about the constitutionality of pleas based on bargains. See Enker, Perspectives on Plea Bargaining, in id, at 108, 111. When a defendant was questioned at the arraignment as to the voluntariness of his plea, he was expected to deny for the record that any promises had been made to him even though both he and the prosecutor knew that bargaining had taken place. See Amendments to Federal Rules of Criminal Procedure: Hearings Before the Subcomm. on Criminal Justice of the House Comm. on the Judiciary, 94th Cong. 1st Sess. 25-26 (1975) (Prof. Leon Friedman) (plea bargaining concealed in federal courts "all the time") [hereinafter cited as House Hearings II]; House Hearings $I$, supra note 21, at 27 (Prof. Frank Remington) (plea bargaining concealed because of questions alsout its propriety).

25. This problem was acknowledged in Santobello. "[I]f [the plea] was induced by promises, the essence of those promises must in some way be made known." 404 U.S. at 
The 1975 Amendments to Rule 11 were an attempt to meet these needs. The Rule now requires a considerably more detailed inquiry into the intelligence and voluntariness of the plea in order to produce the comprehensive record envisioned by $M c$ Carthy. ${ }^{26}$ The Rule also contains procedures for putting plea agreements on the record and seeks in this way to regulate the fairness of the plea bargaining practice that Santobello recognized. ${ }^{27}$

The central event of the Rule 11 hearing is still the colloquy between district judge and defendant. The defendant must be informed of the elements of the charge against him and the minimum and maximum penalties fixed by law; ${ }^{28}$ he must be explicitly warned of the trial rights he waives by pleading guilty. ${ }^{29}$ The judge must also question the defendant about the existence of any circumstances, such as government force or threats, that would endanger the voluntariness of his plea. ${ }^{30}$

After investigating the intelligent and voluntary nature of the defendant's decision to plead guilty, the court must require the government and the defendant to reveal any plea agreements they have made. ${ }^{31}$ The defendant is asked whether he has received any promises

261-62. In the period following Santobello, but prior to the enactment of the 1975 Amendments to Rule 11, several courts of appeals instructed district courts to include procedures designed to put plea bargains on the record in the Rule 11 inquiry. See Moody v. United States, 497 F.2d 359, 365 (7th Cir. 1974); Bryan v. United States, 492 F.2d 775, 780-82 (5th Cir.), cert. denied, 419 U.S. 1079 (1974) (en banc); Paradiso v. United States, 482 F.2d 409, 413 (3d Cir. 1973); Walter v. Harris, 460 F.2d 988, 993 (4th Cir. 1972).

26. Fed. R. Crim. P. 11(c), (d).

27. FED. R. CRIM. P. II(e), (g). These procedures were expected to remove certain abuses that had accompanied unregulated plea bargaining. See 1975 Advisory Committee Notes, supra note 10, at 1304 . First, by recognizing the propriety of plea bargaining and requiring disclosure of agreements, the reforms sought to end the lack of public accountability that inhered in secret bargaining. See Hoffman, supra note 21, at 501. Cf. Newman, The Agnew Plea Bargain, 10 Crim. L. Bull. 85 (1970) (condemning use of plea bargaining by public figures in order to conceal details of their crimes and commending prosecutors in Agnew plea bargain for providing disclosure). Second, by allowing immediate judicial review of the final agreement and the circumstances under which it was reached, the reforms sought to achieve greater fairness and consistency in outcomes. See ABA Guilty Plea Standards, supra note 8, at $\$ 1.8$, Commentary; TAsk Force Rerort, supra note 21, at 10-13. See note 34 infra. Finally, by requiring that if a guilty plea is accepted the judgment must reflect the terms of the bargain, amended Rule Il(e)(3) eliminated the risk to defendants that the court might ignore bargained-for sentencing recommendations made by the prosecutor.

28. Fed. R. CRIM. P. II(c)(1).

29. FED. R. CRIM. P. $11(\mathrm{c})(3)$, (4).

30. FED. R. CRIM. P. 11(d).

31. Fed. R. Crim. P. II(e)(2). Significantly, the duty to reveal plea bargains does not rest on the defendant alone. Cf. ALI Model Code of Pre-Arrignment Procedure $\$ 350.4$ (2) (1975) (court must address "prosecutor and defense counsel and defendant personally" to discover whether plea bargaining has occurred). As one court has observed, "[a]ny attorney, knowing that a promise has been made . . . who allows, in silence, a defendant in effect to deny the fact to the court, must face disciplinary action." United States $v$. Bednarski, 445 F.2d 364, 365 (Ist Cir. 1971). See Meyer v. United States, 424 F.2d 1181, 
other than those contained in the plea agreement. ${ }^{32}$ If the parties have engaged in plea bargaining, Rule 11 gives the district judge discretion to accept or reject the proposed agreement. ${ }^{33}$ By exercising this discretion, district judges may eliminate plea agreements that do not meet judicially evolved standards of fairness and propriety. ${ }^{34}$ Although in-

1198 (8th Cir.), cert. denied, 400 U.S. 853 (1970) (Lay, J., dissenting); Erickson, The Finality of a Plea of Guilty, 48 Notre DAMe LAw. $835,841-43$ (1973).

32. Fed. R. Crim. P. 11(d).

33. Fed. R. Crim. P. 11(e)(2). The Supreme Court has not defined the scope of this discretion. See Santobello v. New York, 404 U.S. 257, 261-62 (1971); North Carolina v. Alford, 400 U.S. 25, $38 \mathrm{n} .11$ (1970). Two appellate courts have limited the use of this discretion. In cases not involving plea bargaining, the-District of Columbia Circuit holds that guilty pleas "should not be refused without good reason." McCoy v. United States, 363 F.2d 306, 307 (D.C. Cir. 1966); see Griffin v. United States, 405 F.2d 1378, 1379-80 (D.C. Cir. 1968). The Fifth Circuit follows the same rule. See United States v. Martinez, 486 F.2d 15, 20-21 (5th Cir, 1973). In plea bargaining cases, these courts distinguish between plea agreements that contain sentence recommendations (a judicial prerogative) and those that contain charge reductions (a prosecutorial prerogative). Although the district judge may refuse to entertain sentencing recommendations even though part of a negotiated plea, see United States v. Maggio, 514 F.2d 80, 89 (5th Cir.), cert. denied, 423 U.S. 1032 (1975), he may not reject bargains based on dismissal of charges unless the agreement represents "an abuse of prosecutorial discretion." United States v. Ammidown, 497 F.2d 615, 622 (D.C. Cir. 1973). See United States v. Maggio, 514 F.2d 80, 91 (5th Cir.), cert. denied, 423 U.S. 1032 (1975) (district judge may not enforce "blanket proscription" of plea bargains involving charge reduction or dismissal). See generally Note, Judicial Discretion to Reject Negotialed Pleas, 63 GEo. L.J. 241 (1974). Other circuits limit district court discretion less stringently. See United States v. Bednarski, 445 F.2d 364, 366 (Ist Cir. 1971) (court should "seriously consider" proffered plea but need not meet standard of District of Columbia Circuit); Maxwell v. United States, 368 F.2d 735, 738-39 (9th Cir. 1966) (court need not accept plea to lesser charge even if government consents).

The 1975 Amendments to Rule 11 take no position on this question. The legislative history makes it clear that the new procedures do not require any district judge to permit plea bargaining in his court. See H.R. ReP. No. 247, 94th Cong., 1st Sess. 6 (1975), reprinted in [1975] U.S. CODE CoNG. \& ADMIN. News 674, 678 [hereinafter cited without parallel citation as House RePoRT]; Federal Rules of Criminal Procedure: Hearings Before the Senate Comm. on the Judiciary, 94th Cong., 1st Sess. 141 (1975) (Rep. Hungate). The Amendments do not attempt to define any criteria for when plea agreements should be accepted or rejected. 1975 Advisory Committee Notes, supra note 10, at 1305.

34. The extent to which courts will use Rule $11(\mathrm{e})$ to review the substance of plea bargains is unclear. In the case of bargains reached by a defendant unrepresented by counsel, the Advisory Committee states that judicial review "is intended to enable the court to reject an agreement... unless the court is satisfied that acceptance of the agreement adequately protects the rights of the defendant and the interest of justice." 1975 Advisory Committee Notes, supra note 10, at 1304. In the case of bargains with counseled defendants, however, acceptance of the plea is "left to the discretion of the individual trial judge." Id. at 1305.

It is possible that judges will be reluctant to reject proffered plea bargains for fear that to do so would "seriously disrupt the flow of guilty pleas." Alschuler, The Trial Judge's Role in Plea Bargaining, Part I, 76 Colum. L. Rev. 1059, 1066-67 (1976). But see Scott v. United States, 419 F.2d 264, 274-78 (D.C. Cir. 1969) (Bazelon, C.J.) (trial courts have an obligation "to supervise the fairness of the bargain"). Yet most commentators have strongly urged that trial judges review the terms of bargains presented to them. See ABA Guilty Ples Standards, supra note 8, at $\$ 3.3(\mathrm{C})$, Commentary; ALI Model Code of Pre-Arraignment Procedurf \$350.5(2) (1975); TAsk Force Report, supra note 21, at $12-$ 13; Enker, supra note 24, at 117-18; Note, Plea Bargaining-Proposed Amendments to Federal Criminal Rule 11, 56 MiN.. L. REv. 718, 732-34 (1972). Commentators have sug- 
dividual judges may refuse to permit any plea bargaining at all in their courts, ${ }^{35}$ their discretion in accepting plea agreements is not similarly unfettered. The 1975 Amendments expressly sanction only four commonly used types of plea bargains, ${ }^{36}$ and the legitimacy of other agreements remains uncertain. ${ }^{37}$ If a given agreement is accepted, it must be reflected in the judgment and sentence imposed by the court. $^{3 s}$ If an agreement is rejected, the defendant must be allowed to withdraw his plea. ${ }^{39}$

Rule 11 requires that a verbatim record be made of the plea-taking proceedings. ${ }^{40}$ Courts are permitted but not required to put defendants on oath during the hearing. ${ }^{41}$

gested two forms of oversight. First, an attempt should be made to ensure that all defendants have an equal opportunity to bargain and that differential bargaining power does not lead to unjustified differentials in sentences. See Newman, Reshape the Deal, 9 Trial, May/June 1973, at 14-15; Note, Restructuring the Plea Bargain, 82 YALE L.J. $286,291-95$ (1972). Second, agreements should be rejected if they would result in sentences that fail adequately to protect the public or otherwise fail to imposc appropriate punishment for the defendant's conduct. See TAsk Forcr Report, supra note 21, at 10, 12-13.

35. See note 33 supra.

36. See Fed. R. Crim. P. 11(e)(1). First, the charge may be reduced to a lesser or related offense. Second, the government may promise to move for dismissal of other charges. Third, the gorernment may agree to recommend or not oppose a particular sentence. Fourth, the government and defense attorncy may agree that a given sentence is an appropriate disposition of the case. 1975 Advisory Commillee Notes, supra note 10 , at 1304. The Advisory Committec apparently meant this list to be exhaustive, referring to the enumerated agreements as the "four possible concessions" the government can offer to obtain a guilty plea. $I d$.

During congressional consideration of the 1975 Amendments, the House Judiciary Committee became concerned that plea agreements requiring defendants to cooperate with the prosecution as part of the bargain might be outlawed by this language. The Committee therefore stated its understanding that a plea agreement could legitimately "bind the defendant to do more than just plcad guilty," e.g,, to testify against a codefendant. House RePORT, supra note 33, at 6 n.8. Of course this proviso, aimed at spelling out what obligations can be placed on the defendant, does nothing to dispel the Advisory Committee's implication that only four specified concessions can be offered by the government.

In United States v. Brighton Bldg. \& Maintenance Co., 431 F. Supp. 1115 (N.D. Ill. 1977), the court rejected a proposed plea bargain incorporating as one of its terms that the case be reassigned to another judge. The court held that Rule 11 "prevent[cd] implementation" of the proposed agreement because the reassignment provision was not one of the concessions authorized by Rule 11 .

37. Many other types of plea bargains have been used in the past. See J. Bond, supra note 9, at 19-2I; Note, Guilty Plea Bargaining: Compromises by Prosecutors to Secure Guilty Pleas, 112 U. PA. L. Rev. 865, 866 n.7 (1964). One type involved prosecutions against third parties. See Alschuler, The Defense Attorney's Role in Plea Bargaining, 84 YALE L.J. 1179, 1211-13 (1975). Another type specified where the defendant would be incarcerated. See Casebeer v. United States, 531 F.2d 949, 952 (9th Cir. 1976). Cf. United States ex rel. Scott v. Mancusi, 429 F.2d 104, 108 (2d Cir. 1970) (defendant desired agreement that would ensure his transfer to Washington, D.C.). Judicial plea bargaining, now forbidden by Rule 11(e)(1), was once prevalent. Sce Alschuler, supra note 34, at 1077-80.

38. FED. R. CRiM. P. $11(\mathrm{e})(3)$.

39. Fed. R. Crim. P. $11(\mathrm{e})(4)$.

40. Fed. R. Crim. P. $11(\mathrm{~g})$.

41. See FED. R. CRIM. P. $11(c)(5)$, (e)(6). These provisions authorize the use of a de- 


\section{The Use of the Rule 11 Record}

A major purpose of the 1975 Amendments in expanding the Rule 11 record was to facilitate prompt disposition of post conviction attacks on guilty pleas. Commentators long had recommended a more thorough examination at the time a plea was taken, reasoning that "the slight additional time spent in careful questioning [would] eliminate most collateral attacks on guilty pleas, thus saving judicial time in the long run." 42 In testimony before Congress, representatives of the Rules Advisory Committee reported that an "underlying concern" in formulating the Amendments was the belief that "a contemporaneous record ... of the circumstances of pleas of guilty" would enable the "validity of subsequent collateral attacks on such pleas [to] be promptly and correctly determined." 43

The Rule 11 hearing can dispose of post conviction attacks in two ways. First, the rule is well established that when the merits of a claim

fendant's statements (other than the guilty plea itself) in a later prosecution for perjury if the statements were made under oath, on the record, and in the presence of counsel. The House Committee report made clear that Rule 11 was not "to be construed as mandating or encouraging the swearing-in of the defendant." House REPORT, supra note 33 , at 7 n.9. Some circuit courts require that defendants be sworn at the Rule 11 hearing. Compare United States v. Hawthorne, 502 F.2d 1183, 1187-88 (3rd Cir. 1974) (defendants must be sworn) and Bryan v. United States, 492 F.2d 775, 781 (5th Cir.), cert. denied, 419 U.S. 1079 (1974) (en banc) (same) with United States v. Journet, 544 F.2d 633, 637 n.6 (2d Cir. 1976) (defendants need not be sworn).

The value of putting defendants under oath is questionable. Presumably, this practice is intended to deter defendants from lying to the court at the time of pleading guilty. Yet, defendants who lie in order to get their plea accepted do so under the influence of secret threats or promises; the remote prospect of a perjury prosecution is unlikely to be an effective deterrent. Also, the threat of an additional sentence has minimal deterrent effect on a defendant who already faces a long jail term. See Wright \& Sofaer, Federal Habeas Corpus for Stale Prisoners: The Allocalion of Fact-Finding Responsibility, 75 YALE L.J. 895, 933 (1966). Finally, since defendants who lie are precisely those who may have had their constitutional rights violated by the government, the result of the oath requirement, if effective, would be to deter prisoners from presenting meritorious claims. Two Congressmen, criticizing the inclusion of the oath provisions in the 1975 Amendments, noted that innocent persons who were coerced to plead guilty could be prosecuted for falsely admitting their guilt. House REPORT, supra note 33, at 37 (separate views of Reps. Holtzman \& Drinan).

42. TAsK Force Rcrort, supra note 21 , at 13 n.30. See Davis, The Guilly Plea Process: Exploring The Issues of Voluntariness and Accuracy, 6 VAL. U.L. REv. I11, 134 (1972); Erickson, supra note 31, at 845-49; Heberling, Judicial Review of the Guilty Plea, 7 Lincoln L. Rrv. 137, 208 (1972); Underwood, Let's Put Plea Discussions-and Agreements -On Record, 1 LoY. CHI. L.J. 1, 5-14 (1970).

43. House Hearings II, supra note 24, at 210 (statement of Judge Lumbard). See 1975 Advisory Commiltee Noles, supra note 10, at 1303; House Hearings $I$, supra note 21, at 25-26 (Rep. Dennis \& Judge Lumbard); id. at 75, 79 (statements of U.S. Attorneys); House Hearings II, supra note 24, at 36, 48 (statement of Charles Sevilla, chief trial attorney, Federal Defenders of San Diego, Inc.). In setting standards for granting evidentiary hearings on post conviction motions, the courts have laid great stress on the need for finality of criminal convictions. See Blackledge v. Allison, 97 S. Ct. 1621, 1628, 1629-30, 1631-32 \& nn.17-19 (1977). For a criticism of the standards the courts have set, see pp. 1414-21 infra. 
have been determined adversely to a petitioner at an adequate judicial hearing, courts are not required to hold another hearing. ${ }^{44}$ To the extent that Rule 11 provides a full and fair hearing on the validity of a guilty plea, therefore, later challenges premised on allegations inconsistent with the Rule 11 findings need not be heard. Second, when a petitioner deliberately has failed to present a claim at a judicial hearing despite an opportunity to do so, his failure under certain circumstances will constitute a waiver of his claim. ${ }^{45}$ Waiver could thus bar defendants from post conviction hearings on guilty pleas if the facts that underpin their attacks were deliberately concealed at the Rule 11 hearing.

\section{A. Rule 11 as a Prior Full Hearing}

In order to act as a full and fair hearing on the validity of a guilty plea, the Rule 11 hearing must conclusively establish the plea's in-

44. See Kaufman v. United States, 394 U.S. 217, 226-27 \& n.8 (1969) (standards for hearing under $\$ 2255$ ); Sanders v. United States, 373 U.S. 1, 15-16 (1963) (standards for successive $\$ 2255$ motions); Townsend v. Sain, 372 U.S. 293, 312-18 (1963) (standards for federal rehearing on questions raised at state hearing). Cf. Swenson v. Stidham, 409 U.S. 224, 229-30, amended, 410 U.S. 904 (1972) (adequate state hearing forecloses right to a federal hearing). See generally Developments in the Law-Federal Habeas Corpus, 83 HARV. L. REV. 1038, 1118-21 (1970).

The Supreme Court, analyzing Rule 11 prior to the 1975 Amendments, observed that the Rule is "designed to eliminate any need to resort to a later fact-finding proceeding." McCarthy v. United States, 394 U.S. 459, 469-70 (1969). See Blackledge v. Allison, 97 S. Ct. 1621,1632 nn.18 \& 19 (1977).

45. To be effective, a waiver must generally represent the defendant's knowing and voluntary decision to forgo the right in question. See, e.g., Brewer v. Williams, 97 S. Ct. 1232, $1241-42$ (1977) (right to counsel); Barker v. Wingo, 407 U.S. 514, 525-26 (1972) (speedy trial rights). Cf. Johnson v. Zerbst, 304 U.S. 458,464 (1938) (waiver is the "intentional relinquishment or abandonment of a known right or privilege"). But see Schneckloth v. Bustamonte, 412 U.S. 218, 235-46 (I973) (consent search; waiver of Fourth Amendment rights valid despite defendant's ignorance of the rights waived). See generally Dix, Waiver in Criminal Procedure: A Brief for More Careful Analysis, 55 TEx. L. REv. 193 (1977).

This standard of knowing and voluntary waiver was applied to claims raised for the first time on post conviction attacks in the "deliberate bypass" standard. Fay v. Noia, 372 U.S. 391, 438-40 (1963). According to Fay, a petitioner's failure to raise a claim at an earlier hearing would not act as a waiver of the claim unless it was the product of a knowing and intentional choice by the petitioner. Id. Recently, however, the Supreme Court has substantially undercut Fay by permitting a waiver of rights to be inferred from the failure to comply with established procedural rules absent a showing of cause for noncompliance and actual prejudice. See Wainwright v. Sykes, 97 S. Ct. 2497 (1977) (failure to comply with state contemporaneous objection rule waives right to object to confession introduced at trial); Francis v. Henderson, 425 U.S. 536 (1976) (failure to raise claim before trial waives right to attack composition of grand jury); Davis v. United States, 411 U.S. 233 (1973) (same). Although there is presently no established procedural rule requiring attacks on guilty pleas to be raised at the Rule 11 hearing to avoid waiver, see note 68 infra, these, cases indicate a new willingness on the part of the Supreme Court to entertain claims of waiver. See also Estelle v. Williams, 425 U.S. 501 (1976) (failure of defendant to object to being tried in prison garb forecloses a later opportunity to be heard). 
telligence and voluntariness. To establish these elements, the Rule 11 judge must make two different types of assessments. First, he must attempt to discover the state of the defendant's understanding in the courtroom at the time of pleading guilty. Second, he must make factual findings about events that occurred outside the courtroom in the past: by questioning the defendant, the judge must try to discover whether the plea is made voluntarily and whether any promises were offered to induce it.

The utility of the Rule 11 record will in large part depend on which of these assessments is the subject of post conviction attack. When the post conviction motion raises questions only about the defendant's understanding at the time of pleading guilty, the record made at the Rule 11 hearing can be dispositive. Because Rule 11 requires that the judge explain to the defendant the charges against him and the consequences of his plea, ${ }^{46}$ the intelligence vel non of the defendant's decision to plead guilty normally is revealed on the record. A reviewing court will be able to determine whether the defendant was sufficiently advised to make an intelligent plea simply by examining this record. ${ }^{47}$ Because Rule 11 also requires the parties to preserve a mutually satisfactory description of any plea agreements they have reached, ${ }^{48}$ the record will contain an objective standard against which later misunderstandings about the terms of the promises can be tested. ${ }^{49}$

When a post conviction motion raises questions about events that occurred outside the courtroom, the Rule 11 record will be far less useful. Typically, the defendant will allege that he was induced to plead guilty by government coercion or by a plea bargain, subsequently broken by the government, that was not revealed at the Rule 11 hearing. Because these inducements may also affect the trustworthiness of

46. See p. 1402 \& notes $28-29$ supra.

47. This was the basis for the Court's holding in McCarthy. The Court noted that, had Rule 11 been carefully complied with,

petitioner's own replies to the court's inquiries might well have attested to his understanding of the essential elements of the crime charged, including the requirement of specific intent, and to his knowledge of the acts which formed the basis for the charge. Otherwise, it would be apparent to the court that the plea could not be accepted.

394 U.S. at 471.

In determining whether a plea is made knowingly, courts focus primarily on the adequacy of the advice given to the defendant. E.g., Henderson v. Morgan, 426 U.S. 637, 644-47 (1976) (reviewing whether the defendant had been given notice of the charges). If the court provides him with all essential advice, later attacks on the intelligence of the plea can be effectively foreclosed. See ABA Gullty Plea Standards, supra note 8, § 1.4, Commentary at 27; Underwood, supra note 42 , at 7 .

48. See pp. 1402-03 \& notes 31-32 supra.

49. See Underwood, supra note 42 , at 9 . 
the defendant's Rule 11 statements, that record cannot be relied upon to dispose of such a post conviction attack. Indeed, to do so would conflict with the Fifth Amendment privilege against self-incrimination.

When allegations of either coercion or concealed government promises are made, the adverse findings of the Rule 11 proceeding will rest primarily on statements by the defendant himself; statements by other parties, such as the prosecution or defense counsel, can do little more than supplement the defendant's own words. ${ }^{50}$ The defendant's statements represent testimony, introduced at a judicial hearing, to establish the existence of facts. Because the facts to be established are the prerequisites of a valid guilty plea, the accused is put in the position of testifying in favor of his own conviction. A defendant's statements, used to establish facts leading to his conviction, must meet Fifth Amendment standards of voluntariness. ${ }^{.1}$

50. In Blackledge v. Allison, $97 \mathrm{~S}$. Ct. 1621 (1977), the Supreme Court suggested that if the defendant's statements are supplemented by statements by the defense counsel and prosecutor and by findings made by the judge in accepting the plea, a "formidable barrier" would be raised to subsequent collateral relief. Id. at 1629 . At present, Rule 11 does not require statements by either the defense or prosecution counsel. But some federal courts do require such statements. E.g., Bryan v. United States, 492 F.2d 775, 781 (5th Cir.), cert. denied, 419 U.S. 1079 (1974) (en banc); Paradiso v. United States, 482 F.2d 409, 413 (3d Cir. 1973); Martinez v. United States, 411 F. Supp. 1352, 1357 (D. N.J. 1976). Even in the absence of such requirements either counsel may make supporting statements.

Unquestionably, statements by the defense or prosecution counsel deserve some weight. At the time a guilty plea is offered, however, all parties presumably desire its acceptance, whatever the means by which the plea may have been obtained. Neither the defendant nor either of the counsel has any interest at this time in having the plea refuscd, and thus none of them will be eager to bring doubtful practices to the court's attention. Sce Rotenburg, The Progress of Plea Bargaining: The ABA Standards and Beyond, 8 ConN. L. REv. 44, 64 (1975); Note, Guilty Plea Bargaining: Compromises by Prosecutors to Secure Guilty Pleas, 112 U. PA. L. REv. 865, 886 (1964); Note, Restructuring the Plea Bargain, 82 YALE L.J. 286, 307 n.68 (1972). Statements by counsel, furthermore, will not have been made under oath or tested by cross-examination, and thus lack the indicia of reliability that ordinarily accompany testimony admitted at a judicial hearing. Cf. California v. Green, 399 U.S. 149, 158 (1970) (noting advantages of in-court over out-of-court testimony). For these reasons, undue weight should not be placed on statements by counsel.

51. The Fifth Amendment privilege against compulsory self-incrimination applies by its terms to "any criminal case." U.S. CoNST. amend. V. In cases defining the scope of the self-incrimination privilege, the Supreme Court has used expansive language. In Kastigar v. United States, 406 U.S. 441, 445 (1972), for example, the Court stated that the privilege "protects against any disclosures that the witness reasonably belicves could be used in a criminal prosecution." Occasionally, the Court has gone further and proffercd a broad objective test, implying that the privilege applies to all statements that could in fact make the imposition of criminal penalties more likely. See, e.g., Lefkowitz v. Turley, 414 U.S. 70, 77 (1973) (quoting McCarthy v. Arndstein, 266 U.S. 34, 40 (1924) (privilege applies "wherever the answer might tend to subject to criminal responsibility him who gives it."))

These formulations of the Fifth Amendment privilege against self-incrimination indicate clearly that the privilege covers statements made by a defendant at a Rule 11 hearing. It has frequently been stated that a valid guilty plea is "more than a con- 
These standards are quite strict. Under the test first articulated in 1897 in Bram $v$. United States, ${ }^{52}$ the Fifth Amendment privilege against self-incrimination forbids the use against a defendant of any statement " 'extracted by any sort of threats or violence [or] obtained by any direct or implied promises, however slight." "\$3 This test bars the use of admissions obtained either by promised benefits ${ }^{54}$ or by actual coercion, such as threats or physical abuse. ${ }^{55}$ The fact that these admissions are made in open court and in the presence of counsel does not eliminate the need to scrutinize their voluntariness; the coercive impact of threats or promises sufficiently potent to induce a defendant to plead guilty will not be dissipated merely by the courtroom setting. ${ }^{56}$ The Bram rule for testing the voluntariness of statements of

fession" and "is itself a conviction." E.g., Boykin v. Alabama, 395 U.S. 238, 242 (1969). Proof of the validity of the plea entered at the Rule 11 hearing obviates the need to prove the defendant's actual guilt at trial. All the considerations of fairness and accuracy that underlie the application of the Fifth Amendment at trial apply with equal force to the Rule Il hearing. If that hearing is intended to establish conclusively the validity of a plea, and hence conviction, the protections deemed essential at trial must be provided.

As the Supreme Court has observed, the act of pleading guilty necessarily requires a waiver of Fifth Amendment rights. See Brady v. United States, 397 U.S. 742, 748 (1970). This waiver, however, extends only to the defendant's admission of guilt in open court and his consent to have judgment entered against him. $C f$. North Carolina v. Alford, 400 U.S. 25, 32, 37 (1970) (guilty plea ordinarily includes both an admission of guilt and consent to conviction although the former is not a "constitutional requisite"). The right not to have improperly obtained admissions used in the conviction proceeding is a separate matter and its waiver cannot be inferred from the waiver implied in a guilty plea.

52. 168 U.S. 532 (1897).

53. Id. at 542.43 (quoting with approval 3 Russell on Crimes 478 (6th ed.)). The Court has consistently adhered to this statement of the test. See Hutto v. Ross, 429 U.S. 28,30 (1976) (per curiam); Malloy v. Hogan, 378 U.S. 1, 7 (1964); Shotwell Mfg. Co. v. United States, 371 U.S. 341, 347-48 (1963).

54. See Hutto v. Ross, 429 U.S. 28, 30 (1976) (per curiam) (confession not the product of "direct or implied promises" held admissible); Shotwell Mfg. Co. v. United States, 371 U.S. $341,347-48$ (1963) (statement procured by promises "can no more be regarded as the product of a free act of the accused than [a statement] obtained by official physical or psychological coercion"); Hunter v. Swenson, 442 F.2d 625, 629-30 (8th Cir. 1971) (confession inadmissible if made in return for promise of reduced charges). See generally Developments in The Law-Confessions, 79 HARv. L. REv. 938, 978-80 (1966). But see ALI Model Code of Pre-Arraignafent Procedure $\$ 150.2(8)$ (1975) (statement obtained by promise of leniency, unlike statement obtained by illegal police coercion, should be admissible if defendant had opportunity to receive adequate advice from counsel). The ALI rule is questionable, for it blurs the distinction between plea bargaining and police interrogation and aliows police to evade the procedures embodied in Rule II to ensure the fairness of the plea bargaining process.

55. See, e.g., Beecher v. Alabama, 389 U.S. 35 (1967) (threat by police officer to kill defendant); Chambers v. Florida, 309 U.S. 227 (1940) (prolonged custodial interrogation); Brown v. Mississippi, 297 U.S. 278 (1936) (whipping by deputy sheriff).

56. In cases involving in-court or "judicial" confessions, courts nonetheless review the circumstances surrounding the defendant's admissions to ensure the absence of coercion. E.g., Thomas v. Arizona, 356 U.S. 390, 400-02 (1958) (although confession was made in "judicial surroundings" before Justice of the Peace, Court reviewed record to determine whether confession had been tainted by prior coercive events). See C. Mc- 
fact that may be used to convict a defendant should, of course, be distinguished from the standards used to test the voluntariness of a guilty plea itself. Although government promises cannot, under Bram, be used to obtain incriminating statements from defendants, under Santobello they may be used to obtain a guilty plea pursuant to a valid plea bargaining agreement.

Under the Bram test, therefore, a defendant can impeach the Rule 11 record by alleging either government coercion or secret government promises in his post conviction motion. When a defendant alleges that his plea was coerced, he will be faced by the fact that he himself denied being coerced at the time the plea was taken. Yet any government coercion powerful enough to induce a defendant to plead guilty and thus consent to immediate conviction would surely be powerful enough to obtain untruthful answers to questions about the plea. ${ }^{57}$ In Fontaine $v$. United States, ${ }^{58}$ the Supreme Court confronted precisely this problem. The petitioner alleged that physical abuse and prolonged police interrogation had induced his plea of guilty. ${ }^{60}$ Without a hearing, the district court denied the petition on the basis of Fontaine's Rule 11 statement that the plea was made voluntarily and without coercion. ${ }^{60}$ The Supreme Court reversed, stating that although Rule 11 was intended to "flush out and resolve" such issues, "its exercise is neither always perfect nor uniformly invulnerable to subsequent challenge calling for an opportunity to prove the allegations." 61

CoRMick, HANDBooK of THE LAW OF Evidence $\$ 160$ (2d ed. 1972) (statements made by defendants in judicial proceedings "admissible if the tests applicable to nonjudicial confessions are met"). The presence of counsel, moreover, is not a reliable safeguard. Defense counsel may be unaware that his client has been pressured to plead guilty. See Machibroda v. United States, 368 U.S. $487,489-90$ (1962). Or the defense attorney may actually participate in the coercive events. E.g., Alesi v. Craven, 440 F.2d 975, 977 (9th Cir.), cert. denied, 404 U.S. 856 (1971); see Alschuler, supra note 37, at 1191-95, 1313.

57. See United States v. McCarthy, 433 F.2d 591, 593 (lst Cir. 1970) ("[I]n cases in which a guilty plea has been improperly induced, most defendants would be expected to deny any impropriety during the Rule Il hearing."); Alschuler, The Supreme Court, The Defense Attorney, and the Guilty Plea, 47 U. Colo. L. Rev. 1, 53 n.172 (1975). Cf. Blackledge v. Allison, $97 \mathrm{~S}$. Ct. 1621, 1629-30 (1977) (recognizing possibility that defendant's Rule 11 statements may be "so much the product of such factors as misunderstanding, duress, or misrepresentation by others" as to open up the plea to collateral attack). The Supreme Court has recognized the same problem in dealing with confessions that include admissions of voluntariness. See Haynes v. Washington, 373 U.S. 503, 513 (1963) ("Common sense dictates the conclusion that if the authorities were successful in compelling the totally incriminating confession of guilt, the very issue for determination, they would have little, if any, trouble securing the self-contained concession of voluntariness."); Haley v. Ohio, 332 U.S. 596, 601 (1948) (plurality opinion of Douglas, J.).

58. 411 U.S. 213 (1973) (per curiam).

59. Id. at 214 .

60. Id. at 213-14.

61. Id. at 215 (footnote omitted). 
When a defendant alleges that his plea was influenced by secret government promises, subsequently broken, parallel reasoning applies. Here again the defendant will be faced with his own disavowal of such promises at the Rule 11 hearing. Yet defendants generally explain their disingenuousness at the hearing by asserting that secrecy was required as part of the bargain. ${ }^{02}$ Under the Bram standard of voluntariness, a defendant cannot be convicted on the basis of statements induced by a government promise of benefits. When a defendant is induced to deny the existence of a secret plea agreement at the Rule 11 hearing because the agreement is conditioned on his silence, the Bram standard will not permit his misrepresentation to foreclose a later claim that the promise was broken, since under Santobello a conviction based on a broken plea bargain cannot stand. The post conviction petitioner, therefore, need only allege that he was required to conceal the promise at the Rule 11 hearing as a condition of the bargain in order to impeach the disclaimer of promises that he made there.

For these reasons, it seems clear that, under the Fifth Amendment, the Rule 11 record cannot be dispositive of post conviction attacks premised on allegations about events that occurred outside the Rule 11 hearing. This conclusion may be restated in pragmatic terms: as a practical matter, a Rule 11 hearing is an unlikely forum for finding out whether government coercion or secret plea bargaining has occurred. Prosecutors and other government agents have concededly used coercive plea tactics in the past, ${ }^{63}$ and coercion sufficient to induce a

62. See, e.g., Machibroda v. United States, 368 U.S. 487, $489-90$ (1962); Bryan v. United States, 492 F.2d 775, 777 (5th Cir.), cert. denied, 419 U.S. 1079 (1974). Frequently, defendants allege that they were advised to conceal the bargain, not by a government official, but by their attorney. E.g., Blackledge v. Allison, 97 S. Ct. 1621, 1626-27 (1977). Because most actual bargaining takes place between prosecutor and defense counsel outside the defendant's presence, courts generally have held that defendants may reasonably rely on their attorney's representation that a bargain exists even if this representation later proves false. See United States v. Hawthorne, 502 F.2d 1183, 1187 (3rd Gir. 1974); Mosher v. LaVallee, 351 F. Supp. 1101, 1109-10 (S.D.N.Y. 1972), aff'd, 491 F.2d 1346 (2d Cir.), cert. denied, 416 U.S. 906 (1974). For the same reason, defendants may generally be expected to rely on their attorney's warning that a bargain must be concealed, and the fact that the concealment owes to the advice of defense counsel rather than of the prosecution should be irrelevant. See Blackledge v. Allison, 97 S. Ct. 1621, 1631 (1977) (if defendant had been "advised by counsel to conceal any plea bargain, his denial that any promises had been made might have been a courtroom ritual more sham than real") (citation omitted); Edwards v. Garrison, 529 F.2d 1374, 1379 (4th Cir. 1975), cert. denied, 424 U.S. 950 (1976).

63. See Ali Model Code of Pre-Arraignment Procedure $\$ 350.3$, Commentary at 615 (1975); Freedman, The Professional Responsibility of the Prosecuting Attorney, 55 GEo. L.J. 1030, 1035-36 (1967). A recent study of the prevalence of guilty pleas in various federal districts concluded that prosecutors in some districts obtained numerous convictions through guilty pleas in cases in which the defendant would not have been convicted at trial. See Finkelstein, supra note 21. The author suggested that his findings 
plea of guilty will not be uncovered by inquiries directed to the defendant. The same is true of plea bargaining. Even after any real doubts about the propriety of plea bargaining had dissipated, some bargains continued to be concealed. ${ }^{64}$ Ordinarily both the defendant and prosecution will find it in their interest to put promises on the record, ${ }^{65}$ but the fear of judicial disapproval may give them an incentive to bargain secretly. ${ }^{66}$ Where an illegitimate bargain has been reached, it is unrealistic to expect that the parties will reveal it. If the alleged abuses actually occurred, then there is good reason to believe that the Rule 11 proceeding will fail to discover them. It would seem unwise to rely on prior findings obtained by methods so unlikely to be effective in determining the facts.

should be interpreted to show the need for "more particularized judgments" about the voluntariness of pleas. Id. at 295 . Because the study relied on statistical analysis rather than on observations in the field, however, it cannot be taken as evidence that prosecutorial behavior has in fact exceeded the limits set by the Supreme Court.

64. See, e.g., United States v. Rapp, 539 F.2d 1156, 1158 (8th Cir. 1976) (post-Santobello); Rosado v. United States, 510 F.2d 1098 (5th Cir. 1975) (pre-Santobello but postBrady); Karger v. United States, 388 F. Supp. 595, 597 (D. Mass. 1975) (same). In Rosado the defendant signed a sworn statement that no secret bargains or promises had been made to induce his plea and then pled guilty to a charge for which the court informed him that he had a complete defense. Id. at 1100. Subsequently, the prosecutor dropped three related counts that had been brought under another statute. Id. at $1100 \mathrm{n}$.I. In reviewing the defendant's post conviction motion, the court refused to order an inquiry into the possible existence of plea bargaining.

65. See Underwood, supra note 42 , at 9.

66. Plea bargaining was routinely concealed during the years when doubts about its propriety persisted. See note 24 supra. Even after Santobello and the 1975 Amendments to Rule Il, however, many restrictions on the parties' freedom to bargain remain. Only certain types of agreements are legitimated by the Rule, and others may be disapproved by implication. See note 36 supra. District judges are given discretion to accept or reject any particular plea agreement, see note 33 supra, and some judges may refuse to allow plea bargaining at all, see notes $21 \& 34$ supra, or may refuse to consider certain types of agreements even though they are authorized by Rule 11. See note 33 stupra; United States v. Martin, 409 F. Supp. 155, 157 n.1 (IV.D. Mo. 1975) (district court twice refused proffered guilty plea because it was "induced by a plea bargain which was unacceptable to the Court."). If judges attempt to regulate the fairness of the bargains reached by the parties, see note 34 supra, additional impediments to bargaining freedom will arise. These impediments may lead to continued secret bargaining. See Comment, 14 AM. Crim. L. REv. 305, 314 \& n.46 (1976) (suggesting that limits on the parties' freedom to bargain may generate secret bargaining).

In 1973, New York enacted statutory controls on plea bargaining, now substantially modified, in an attempt to increase penalties for drug offenses. After indictment for specified drug offenses, the law limited the entrance of a guilty plea to a lesser included offense. 1973 N.Y. Laws, ch. 276, $\$ 23.6$ (McKinney) (current version at N.Y. Crim. Proc. LAw $\$ 220.10(5)$ (McKinney 1977)); see Signorelli, $A$ Judicial Analysis and Critique of the New Drug and Sentencing Laws, 46 N.Y. ST. B.J. 9, I1-12 (1974). As a result of the law, many defendants, particularly minor offenders, chose to go to trial. In 1975, the backlog of drug cases in New York City alone reached 1,600. N.Y. Times, Feb. 21, 1975, at 61, col. 3. This pressure caused courts and prosecutors to circumvent the prohibition on plea bargaining by striking bargains prior to the time of indictment. N.Y. Times, Feb. 11, 1975, at 78, col. 2. See Signorelli, supra at 19 . 


\section{B. Waiver and the Rule 11 Hearing}

Even if the Rule 11 hearing did not itself adequately determine the merits of a later claim, a finding of waiver could provide an alternative basis for dispensing with a hearing. ${ }^{67}$ At the time a guilty plea is taken, the defendant obviously will be aware of any threats or promises that have been made to him, and the required judicial inquiry into these matters gives him an ample opportunity to voice his objections. Arguably, his failure to do so at the Rule 11 hearing may constitute a waiver of his claims. ${ }^{68}$

Yet waiver is an inappropriate ground for denying hearings. This is clearest when the defendant claims that he was compelled to plead guilty by government threats or other misconduct. If coercion actually occurred, it would be wholly unrealistic to expect the defendant to mention it at the time his plea was taken. As the Supreme Court has observed, if a plea is "so coerced as to deprive it of validity to support [a] conviction, the coercion likewise deprive[s] it of validity as a waiver of [the defendant's] right to assail the conviction."69

Waiver is also inappropriate when the defendant claims that the government broke a secret plea bargain. In this case, the defendant seeks to assert his Santobello right to have plea promises enforced. His deliberate concealment of the promise at the Rule 11 hearing, it may be argued, should constitute a waiver of the right to have it enforced. Yet the act of concealment can scarcely be termed a product of the defendant's free choice. Defendants who engage in secret plea bargaining may well have been induced to surrender the protection of putting plea agreements on record in exchange for promised benefits unavailable through Rule 11 procedures. ${ }^{70} \mathrm{~A}$ defendant's election

67. See note 45 supra.

68. Most courts have ignored the possibility of waiver in reviewing post conviction attacks on guilty pleas. In the Third Circuit, however, district judges are advised, among other things, to warn the defendant when pleading guilty that "he may not at a later time contend that any promise, representation, agreement or understanding was made ... other than that set forth in open court." United States v. Valenciano, 495 F.2d 585, 588 (3d Cir. 1974). See United States v. Hawthorne, 502 F.2d 1183, 1187-88 (3d Cir. 1974) (Valenciano warnings are mandatory). Despite this requirement, the Third Circuit has not actually barred subsequent allegations of concealed plea bargains on grounds of waiver. Rather, the court has viewed its warning as a means of deterring defendants from misrepresenting facts in Rule 11 hearings by threatening a perjury prosecution. Id. at $1187,1188$.

69. Waley v. Johnston, 316 U.S. 101, 104 (1942).

70. Indeed, since it will generally be in the defendant's interest to put plea agreements on record, see p. 1412 \& notes 27,65 supra, it is difficult to suggest other motives for concealment.

To be sure, the fact that the promise is off the record creates an evidentiary problem for the post conviction petitioner who must prove that a promise was made but not kept. A finding of waiver, however, would strip the defendant of the right to assert a post conviction claim whether proof was available or not. 
to conceal the promises made to him would thus be the direct result of the government's condition of secrecy-an interference with free choice that should nullify any suggestion of waiver. ${ }^{71}$

\section{Finality and Rule 11}

This Note argues that it will often be impossible to dispose of post conviction attacks on guilty pleas by reference to the record made at the Rule 11 hearing. In such cases an evidentiary hearing on the post conviction motion will have to be held. By depriving many convictions based on guilty pleas of finality, this conclusion entails important consequences for the criminal justice system.

The American criminal justice system depends heavily on guilty pleas. To provide a trial to every person charged with a criminal offense would require a vast expansion of the resources allocated to the administration of the criminal law. ${ }^{72}$ In legitimating plea bargaining the Supreme Court expressly acknowledged this fact, ${ }^{73}$ and regarded its decisions as a means of ensuring that the stream of guilty pleas would continue.

71. Courts have often refused to recognize waivers made under analogous conditions. See, e.g., Lefkowitz v. Turley, 414 U.S. 70, 82-83 (1973) (waiver of Fifth Amendment privilege "secured under threat of substantial economic sanction" invalid because involuntary); Marchetti v. United States, 390 U.S. 39, 51-52 (1968) (no waiver of Fifth Amendment rights where government presents gambler with choice of abandoning gambling or providing evidence incriminating to himself); cf. McKnight v. United States, 507 F.2d 1034, 1036-37 (5th Cir. 1975) ( $\$ 2255$ motion not barred by failure to appeal if decision to forgo appeal not made voluntarily).

In the case of Santobello claims, there is a particular need to provide hearings in order to deter attempts by the prosecution to evade Rule 11 limits on plea bargaining. See note 27 supra (1975 Amendments intended to end secrecy and lack of accountability to judicial control of plea bargaining). By relieving the government of its responsibility to carry out plea bargain commitments not revealed at the Rule 11 hearing, this application of the doctrine of waiver would create dangerous incentives for prosecutors to bargain off the record. See note 66 supra.

Furthermore, there is little prejudice to prosecution interests in allowing such claims to be heard. For other types of claims the government may be unable to retry a defendant if a constitutional claim, not asserted in a timely fashion, is found meritorious in a post conviction attack. See Henderson v. Kibbe, 97 S. Ct. 1730, 1737 n.13 (1977) (collateral attack "may be made many years after the conviction when it may be impossible, as a practical matter, to conduct a retrial"); Friendly, Is Innocence Irrelevant? Collateral Attack on Criminal Judgments, 38 U. CHI. L. REv. 142, 147 (1970) (inability to retry defendant "even more likely" where conviction based on guilty plea because of lack of trial transcript). This presents no problem for Santobello claims. Because one recognized remedy for a broken plea bargain is specific performance of the promise made, see note 22 supra, relief can be fashioned in such a case without requiring a new trial if the government has been prejudiced by the delay.

72. See Santobello v. New York, 404 U.S. 257, 260 (1971) ("If every criminal charge were subjected to a full-scale trial, the States and the Federal Government would need to multiply by many times the number of judges and court facilities."); note I supra.

73. 404 U.S. at 260-6l; Brady v. United States, 397 U.S. 742, 752-53 (1970).

\section{4}


In view of this heavy dependence on guilty pleas, any liberal policy of granting hearings when guilty pleas are attacked may seem quixotic. Such hearings unquestionably will intensify the already considerable strain that post conviction petitions place on courts and correctional institutions. ${ }^{74}$ Indeed, such hearings may well cancel out much of the savings in judicial time and resources that the reliance on guilty pleas was meant to produce. ${ }^{75}$

Against these considerations of judicial economy must be balanced the central purpose of the system of post conviction remedies: to protect human liberty. ${ }^{70}$ This purpose inevitably will be frustrated unless a hearing is given to every petitioner who advances a colorable claim for relief. In any case in which the Rule 11 record fails to negate conclusively the allegations of wrongdoing or to form the basis for a finding of valid waiver, there is simply no way to know if a claim is baseless unless it is heard.

This conclusion, not surprisingly, has proven unpalatable to many courts, and judicial techniques have been devised for concluding post conviction attacks without a hearing, or with only a limited one. Because a guilty plea forecloses the procedural safeguards available at trial, however, these techniques must be carefully scrutinized to ensure that no unfairness is visited upon defendants who plead guilty. ${ }^{77}$ On

74. For judicial observations on the costs entailed in hearing post conviction attacks, see Blackledge v. Allison, 97 S. Ct. 1621, 1628 (1977); id. at 1634-35 (Powell, J., concurring); Schneckloth v. Bustamonte, 412 U.S. 218, 256.66 (1973) (Powell, J., concurring); Sanders v. United States, 373 U.S. 1, $23-26$ (1963) (Harlan, J., dissenting). The most significant cost is the judicial time consumed in processing the claims, the vast majority of which prove unfounded. In 1974, federal prisoners filed 1,822 motions to vacate sentence and 1,718 petitions for habeas corpus-a total of 3,540 post conviction petitions and an increase of 524 over the preceding year. [1974] AD. OF. OF THE U.S. CouRTs ANN. REP. 221. Federal courts fail to grant the relief requested in $96 \%$ of all prisoner cases. [1971] AD. OF. OF THE U.S. Courts ANN. REP. 132. In fact, however, few cases receive an evidentiary hearing. See note 92 infra (tabulating cases).

Some observers doubt whether the relitigation of facts in a hearing long after the original conviction will exceed or even equal the accuracy of the job originally done. See Bator, Finality in Criminal Law and Federal Habcas Corpus for State Prisoners, 76 Harv. L. Rev. 441, 446-53 (1963); Developments in the Law-Federal Habeas Corpus, 83 Harv. L. Rev. 1038, 1120 \& n.39 (1970). Cf. F. James, Civil Procedure 518 (1965) (arguing that since any relitigation will have its own errors, the point of diminishing returns may be reached after one full hearing).

75. "To allow indiscriminate hearings in federal postconviction proceedings ... would eliminate the chief virtues of the plea system-speed, economy, and finality." Blackledge v. Allison, 97 S. Ct. 1621, 1628 (1977).

76. See id. at 1628 ("very purpose" of habeas corpus is "to safeguard a person's freedom from detention in violation of constitutional guarantees"); $c f$. Sanders v. United States, 373 U.S. 1, 8 (1963) ("Conventional notions of finality of litigation have no place where life or liberty is at stake and infringement of constitutional rights is alleged.")

77. Cf. Sanders v. United States, 373 U.S. 1, 22 (1963) (the "summary nature" of conviction by guilty plea enhances need for access to post conviction review). 
balance, it seems that these techniques will be ineffective or will be effective only by sacrificing fairness.

\section{A. Judicially Evolved Techniques}

Even though there is no assurance that the Rule 11 hearing will catch violations at the time the guilty plea is entered, some courts have viewed the availability of the Rule 11 record as justifying a requirement that petitioners attacking guilty pleas make certain initial showings. ${ }^{78}$ This requirement has taken two forms.

Some circuits have imposed a requirement of additional factual pleading. ${ }^{79}$ In Crawford $v$. United States, ${ }^{80}$ the Fourth Circuit adopted the rule that the "accuracy and truth" of a defendant's Rule 11 statements will be deemed conclusively established unless he alleges facts that show a reasonable excuse to set those statements aside. ${ }^{81}$ In this

78. In a general way, the Supreme Court endorsed these efforts in Blackledge. Although the Court recognized that there could be no "per se" rule denying hearings to those who plead guilty, $97 \mathrm{~S}$. Ct. at 1629-30, it suggested that if procedures comparable to Rule 11 are scrupulously followed petitioners will be entitled to evidentiary hearings "only in the most extraordinary circumstances." Id. at 1632 n.19. The Court did not elaborate as to what circumstances would be sufficiently extraordinary to warrant a hearing.

79. A $\$ 2255$ petition must meet factual pleading requirements that go well beyond those for most civil pleadings. The Federal Rules of Civil Procedure require only "notice pleading" for civil complaints generally-allegations sufficient to inform the other parties to the litigation of the nature of the claim being asserted. FED. R. Civ. P. 8(a); see Conley v. Gibson, 355 U.S. 41, 47-48 (1957). A $\$ 2255$ petition, however, must state particular facts sufficient to establish a claim for relief. See Developments in the Law-Federal Habeas Corpus, 83 HARv. L. Rev. 1038, 1173.74 \& n.127 (1970) (citing authorities). Courts, moreover, have a limited discretion not to hear claims whose allegations the court finds "palpably incredible." Blackledge v. Allison, 97 S. Ct. 1621, 1630 (1977) (citing Machibroda v. United States, 368 U.S. 487, 495 (1962)).

In Blackledge, the Court intimated that if procedures similar to those currently embodied in Rule 11 had been followed when the guilty plea was taken, any subsequent allegations of a secret unkept promise might be too unbelievable to warrant a hearing. $97 \mathrm{~S}$. Ct. at 1630-32. The Court's suggestion is disingenuous. It would be quite proper to suggest that if the Rule 11 procedures were sufficient to constitute a full and fair hearing on the merits of a claim, one hearing would suffice. See pp. 1405.06 \& note 44 supra. But to suggest that procedures that are inadequate to produce a binding adjudication on the merits can nevertheless make a petitioner's allegations so unlikcly to be true as to warrant summary dismissal is to render the requirement of a full and fair hearing nugatory. See Sanders v. United States, 373 U.S. 1, 22 (1963) (applicant for post conviction relief should not be "cursorily dismissed because his claim seems unlikely to prove meritorious. That his application is vexatious or repetitious, or that his claim lacks any substance, must be fairly demonstrated.") This is not to say that some allegations attacking guilty pleas are not so authentically incredible so as to dispense with the need for a hearing. E.g., Bryan v. United States, 492 F.2d 775, 779-80 (5th Cir.), cert. denied, 419 U.S. 1079 (1974) (en banc).

80. 519 F.2d 347 (4th Cir. 1975), cert. denied, 423 U.S. 1057 (1976).

81. Id. at 350. The court continued, "[W]e hold that a defendant should not be heard to controvert his Rule 11 statements in a subsequent $\$ 2255$ motion unless he offers a valid reason why he should be permitted to depart from the apparent truth of his earlier statement." Id. See, e.g., Edmonds v. Lewis, 546 F.2d 566, 568 (4th Cir. 
way, it was hoped that petitions alleging facts inconsistent with the Rule 11 record could be dismissed without a hearing. Other circuits have adopted similar rules. ${ }^{82}$

Requiring a petitioner to plead facts sufficient to impeach the Rule 11 record is consistent with the general principle that an adequate prior hearing will eliminate the need for a second hearing. Yet because the Rule 11 record is quite vulnerable to attack, this barrier is hardly a formidable one. In practice, petitioners have generally had little trouble in alleging an excuse sufficient to overturn their original statements. ${ }^{83}$

An alternative approach, adopted by the Fifth Circuit, has been more effective in dispensing with hearings on guilty plea attacks. Beginning with Bryan $v$. United States, ${ }^{84}$ that court has refused to grant hearings on petitions whose allegations contradict the petitioner's Rule 11 statements. In order to overcome this contradiction, a petitioner must support his claim with reliable third party affidavits or other documents. ${ }^{85}$ Instead of focusing on the adequacy of the Rule 11

1976) (excuse offered by petitioner insufficient to warrant evidentiary hearing); Edwards v. Garrison, 529 F.2d 1347, 1377 (4th Cir. 1975), cert. denied, 424 U.S. 950 (1976) (allegation of secret plea bargain sufficient excuse to warrant evidentiary hearing).

82. See United States v. Williams, 536 F.2d 247, 249-50 (8th Cir. 1976) (embracing Crawford rule); Hedman v. United States, 527 F.2d 20, 22 (10th Gir. 1975) (same, without attribution); United States v. Hawthorne, 502 F.2d 1183, 1185-88 (3d Cir. 1974) (reasonable reliance by defendant on counsel's misrepresentations about existence of out-ofcourt "arrangement" warrants evidentiary hearing).

83. The Fourth Circuit has decided five cases applying the Crawford rule. Of these, the petitioner's excuse was found sufficient in four. Allison v. Blackledge, 533 F.2d 894 (4th Cir, 1976), aff'd, 97 S. Ct. 1621 (1977); Edwards v. Garrison, 529 F.2d 1374 (4th Cir. 1975), cert. denied, 424 U.S. 950 (1976); Bass v. United States, 529 F.2d 1374 (4th Cir. 1975); United States v. Hammerman, 528 F.2d 326 (4th Cir. 1975). Only in Edmonds v. Lewis, 546 F.2d 566 (4th Cir. 1976), was a hearing denied. See Allison v. Blackledge, 533 F.2d at 899 (Field, J., concurring specially) ("A distillation of these decisions demonstrates ... that no matter how searching the inquiry of the court may be on the issue of voluntariness, no trial judge, state or federal, can protect himself against a later complaint by a convicted criminal" that his rights were violated.)

Other circuits that have embraced the Crawford rule have had greater success in eliminating hearings. E.g., United States v. Williams, 536 F.2d 247 (8th Cir. 1976) (denying hearing on allegations of promises by defense attorney); Hedman v. United States, 527 F.2d 20 (10th Cir. 1975) (denying hearing on allegations of involuntary plea and ineffective assistance of counsel).

84. 492 F.2d 775 (5th Cir.), cert. denied, 419 U.S. 1079 (1974) (en banc). For cases implementing Bryan, see, e.g., Clayton v. Estelle, 541 F.2d 486, 488 (5th Cir. 1976); United States v. Barrett, 514 F.2d 1241, 1243 (5th Cir. 1975). See generally 53 TEx. L. REv. 147 (1974) (discussing Bryan). In Bryan, the court asserted that it would treat each case on its individual merits rather than create a "per se" rule. 492 F.2d at 778. After $B r y a n$, however, only cases with substantial documentary support have received hearings. See Matthews v. United States, 533 F.2d 900, 902-03 (5th Cir. 1976), cert. denied, 97 S. Ct. 1156 (1977).

85. See Matthews v. United States, 533 F.2d 900 (5th Cir. 1976), cert. denied, 97 S. Ct. 1156 (1977) (affidavit of counsel); Vandenades v. United States, 523 F.2d 1220 (5th Cir. 1975) (letter from sentencing judge); Dugan v. United States, 521 F.2d 231 (5th Cir. 1975) (affidavit of sheriff and deputy). 
hearing, this rule puts the burden on the defendant to make an affirmative showing that his claim is likely to succeed on the merits. Not surprisingly, most petitions have failed to meet this stringent standard. ${ }^{86}$

Despite its utility in avoiding hearings, the Fifth Circuit rule sweeps too far. In relying on the presumed accuracy of the Rule 11 record, it makes no allowance for the possibility that the original hearing was flawed. Factual allegations sufficient to void the Rule 11 record are simply ignored. ${ }^{87}$ Courts may thus deny hearings on the basis of a record tainted with statements obtained by secret promises or coercion. Moreover, requiring petitioners to produce evidence in support of their claims at such an early stage may place an unfair burden on them. Post conviction petitioners who must proceed pro se while incarcerated will usually lack the ability to marshal evidence that would otherwise be available. ${ }^{88}$ If claims are dismissed for failure

86. For cases denying hearings, see Goodwin v. United States, 544 F.2d 826 (5th Cir. 1977); Clayton v. Estelle, 541 F.2d 486 (5th Cir. 1976); Johnson v. Massey, 516 F.2d 1001 (5th Cir. 1975); United States v. Barrett, 514 F.2d 1241 (5th Cir. 1975); Jackson v. United States, 512 F.2d 772 (5th Cir. 1975); Rosado v. United States, 510 F.2d 1098 (5th Cir. 1975); Frank v. United States, 501 F.2d 173 (5th Cir. 1974). For cases ordering hearings, see note 85 supra.

87. In United States v. Barrett, 514 F.2d 1241 (5th Cir. 1975), the court, relying on Bryan, refused to allow a hearing on a claim that lengthy pre-trial incarceration under substandard jail conditions had coerced the petitioner's guilty plea. The claim, if proven, probably would have sufficed to set the plea aside. See Prettyjohn v. United States, 419 F.2d 651, 660 (D.C. Cir. 1969), cert. denied, 397 U.S. 1058 (1970) (statement of Bazelon, C.J.) (defendant's guilty plea induced by jail conditions may be vulnerable to collateral attack for involuntariness). The court, however, ignored facts in the record supporting Barrett's claim. Conditions at the jail in which Barrett had been confined had been found by a federal judge to constitute cruel and unusual punishment, 514 F.2d at 1242, and Barrett had complained to his attorney that his health was suffering from them, id. at 1243. If Barrett had indeed pled guilty to escape inhuman jail conditions, he would hardly have made Rule Il statements inconsistent with having the plea acceptedsuch as that the plea was involuntary.

In Frank v. United States, 501 F.2d 173 (5th Cir. 1974), the court also refused to order a hearing, this time on a claim that a plea bargain concealed at the Rule 11 hearing had been broken by the government. Frank alleged that his attorney had instructed him to conceal the promise when he pled guilty. 501 F.2d at 174. If true, this allegation would provide an excuse for concealment. See note 62 supra.

88. Dissenting in Bryan, Judge Goldberg pointed out that under a rule requiring a prisoner to produce competent evidence other than his own affidavit as a condition of receiving a hearing, the "realities of prison life" could "unreasonably and unnecessarily" restrict access to hearings. 492 F.2d at 783 (Goldberg, J., concurring in part and dissenting in part). See Harris v. Nelson, 394 U.S. 286, 291 (1969) ("the petitioner, being in custody, is usually handicapped in developing the evidence needed to support in necessary detail the facts alleged in his petition").

In Blackledge v. Allison, 97 S. Ct. 1621 (1977), the district court had dismissed Allison's petition for habeas corpus upon the recommendation of the United States Magistrate to whom the matter had been referred. The Magistrate recommended dismissal after Allison failed to comply with instructions to supply notarized statements supporting his allegations from a codefendant, confined in a different prison, who had allegedly 
to come forward with affidavits at a time when petitioners have the benefit neither of discovery nor of counsel, meritorious as well as frivolous claims will be barred.

\section{B. Procedures for Summary Disposition}

The large number of frivolous post conviction petitions has underscored the need for procedures to dispose of such attacks summarily. The newly adopted Rules Governing Section 2255 Proceedings for the United States District Courts offer a variety of procedures designed to test the factual basis of a petitioner's claim without a full fact-finding hearing. In appropriate cases, a broad range of discovery tools is available to the parties. ${ }^{89}$ Through procedures for expanding the record, affidavits and other documents relevant to resolving the merits of a claim can be put before the court. ${ }^{90}$ All these documents are considered in making the decision whether or not to hold an evidentiary hearing.

Unfortunately, the most troublesome cases are those turning on

witnessed the events in question. Id. at 1627,1634 n.26. The Supreme Court disapproved of this action, noting that it "imposed upon Allison a novel and formless burden of supplying proof, without the benefit of compulsory process and without any intimation that dismissal would follow if that burden were not met." Id. at 1634 n.26. For an analysis of the problems facing an incarcerated litigant who must proceed pro se, see Note, The Jailed Pro Se Defendant and the Right to Prepare a Defense, 86 YALE L.J. 292, 304-07 (1976).

89. SeCtion 2255 RuLes, supra note 5, Rule 6.

For a discussion of the use of pre-hearing discovery in habeas corpus petitions filed by state prisoners under 28 U.S.C. $\S 2254$, see Notes of the Advisory Committee, Rules Governing Section 2254 Cases in the United States District Courts, Rule 6, reprinted in 28 U.S.C.A. foll. $\$ 2254$, at 339.40 (West Supp. 1977) [hereinafter cited as $\$ 2254 A d$ visory Committee Notes]. In habeas cases, it is contemplated that pre-hearing discovery will eliminate some evidentiary hearings, as by showing that there are "'no disputed issues of law or fact.'" Id. at 340 (quoting Developments in the Law-Federal Habeas Corpus, 83 Harv. L. Rev. 1038, 1181 (1970)). The Committee conceded, however, that pre-hearing discovery will "probably not [be] as frequently sought or granted as discovery in conjunction with a hearing." Id. The Advisory Committee stated that this discussion of discovery under the $\$ 2254$ Rules governing state prisoners "is fully applicable to discovery under these rules for $\S 2255$ motions" filed by federal prisoners. Notes of the Advisory Committee, Rules Governing Section 2255 Proceedings for the United States District Courts, Rule 6, reprinted in 28 U.S.C.A. foll. \$ 2255, at 110 (West Supp. 1977) [hereinafter cited as $\$ 2255$ Advisory Committee Notes].

90. In cases that survive summary dismissal, the court "may direct that the record be expanded" to include affidavits, "Ietters predating the filing of the motion in the district court, documents, exhibits, and answers under oath, if so directed, to written interrogatories propounded by the judge." SECrion 2255 Rules, supra note 5, Rule 7(a), (b). See Raines v. United States, 423 F.2d 526, 529-30 (4th Cir. 1970) (discussing disposition on an expanded record). The main purpose of this rule is to "enable the judge to dispose of some habeas petitions not dismissed on the pleadings, without the time and expensé required for an evidentiary hearing" and thus to "eliminate some unnecessary hearings." $\$ 2254$ Advisory Committee Notes, supra note 89, at 341 (adopted for $\S 2255$ proceedings in $\$ 2255$ Advisory Committee Notes, supra note 89, at 110). 
contested issues of fact, ${ }^{91}$ and where such conflicts exist there is little hope that an evidentiary hearing can be avoided.92 A hearing may be unnecessary, of course, if the procedures show that the petitioner can obtain no evidence to support his claim. ${ }^{93}$ But expansion of the record through discovery or affidavits can produce only documentary forms of evidence. In guilty plea cases the critical events will generally have taken place in the petitioner's presence and with his participation, ${ }^{94}$

91. If it "plainly appears from the face of the motion" and accompanying record that the petitioner's claim is unfounded, summary dismissal by the district judge is permitted. Section 2255 Rules, supra note 5, Rule 4(b).

92. Prior to the enactment of the new Rules, a majority of the petitions that escaped summary dismissal raised factual issues necessitating an evidentiary hearing. See $\$ 2254$ Advisory Committee Notes, supra note 89, at 342 . A compilation of statistics for $\$ 2255$ motions between the years 1970 and 1974 reveals the following pattern.*

$\begin{array}{lcccc}\text { fiscal } & \begin{array}{c}\text { total \# of } \\ \text { cases receiving } \\ \text { court action }\end{array} & \begin{array}{c}\text { \# cases } \\ \text { disposed of } \\ \text { before pretrial } \\ \text { conference }\end{array} & \begin{array}{c}\text { \# of cases } \\ \text { disposed of } \\ \text { during or } \\ \text { after pretrial } \\ \text { conference }\end{array} & \begin{array}{c}\text { \# of cases } \\ \text { disposed of } \\ \text { at trial }\end{array} \\ 1970 & 1,627 & 1,525 & 10 & 92 \\ 1971 & 1,404 & 1,314 & 13 & 77 \\ 1972 & 1,549 & 1,508 & 6 & 35 \\ 1973 & 1,676 & 1,617 & 8 & 51 \\ 1974 & 1,792 & 1,740 & 5 & 47 \\ \text { Total } & 8,048 & 7,704 & 42 & 302\end{array}$

* Data taken from [1970-74] Ad. Of. of the U.S. Courts ANN. Rep. Table C-4.

93. Section 2255 Rules, supra note 5, Rule 4(b).

In Blackledge v. Allison, 97 S. Ct. 1621 (1977), the Supreme Court noted that, "[a]s in civil cases generally," a petition for habeas corpus filed in federal court by a state prisoner is subject to a motion for summary judgment by the state. Id. at 1632-33. Through such a motion, the state can test whether the allegations of the petition have "sufficient basis in fact to warrant plenary presentation of evidence." Id. It is not clear whether this procedure would also be available to test a $\$ 2255$ motion by $a$ federal prisoner. Unlike a writ of habeas corpus, a $\$ 2255$ petition represents "a further step in the movant's criminal case" rather than a separate civil action. $\$ 2255$ Advisory Committee Notes, supra note 89, at 104-05. But see id. at 111 (standards for granting hearing on $\S 2255$ motion "essentially the same" as those applied to habeas petition).

Whether summary judgment is directly available in $\$ 2255$ motions or not, the rules governing summary judgment suggest reasonable limits on federal courts' summary dismissal of $\$ 2255$ motions. See note 95 infra. A prisoner sceking relief should not be denied a hearing for failure to come forward with affidavits or other documentary evidence until the government has made an initial factual showing that his claim is without merit. FED. R. Civ. P. 56(e). When affidavits are demanded, the $\$ 2255$ petitioner's own affidavit should be sufficient for matters of which he has personal knowl. edge, id., and the petitioner should be given an opportunity to escape dismissal by showing that essential affidavits are unobtainable, FED. R. Crv. P. 56(f). Finally, a case should not be disposed of by affidavits as long as there remains a "genuine issue as to any material fact." FED. R. Civ. P. 56(c). Thus, when the affidavits submitted by the petitioner and government contain conflicting versions of the pivotal events, an evidentiary hearing should be required.

94. Attacks on guilty pleas that focus either on the intelligent or voluntary nature of the plea or on the existence of unkept plea bargains necessarily involve events in 
and fairness demands that he be allowed to pit his credibility against that of opposing witnesses before the factfinder. ${ }^{95}$ Thus, when a petitioner alleges facts that would entitle him to relief and that refer to events in which he personally participated, a new hearing ordinarily will be required.

\section{Conclusion}

The conclusion of this analysis can be stated simply: post conviction motions attacking guilty pleas need to be heard. This conclusion should not be taken to imply that the 1975 Amendments to Rule 11 have failed. The comprehensive hearing held at the time the plea is taken can succeed in eliminating later hearings when attacks are made on the knowing and intelligent character of a plea. ${ }^{96}$ More importantly, the Rule 11 hearing can be expected to prevent some violations of defendants' rights from occurring at all. ${ }^{9 \tau}$ The fact remains, however, that even a reformed Rule 11 cannot eliminate the need for post conviction hearings when attacks are directed at events that transpired outside the Rule 11 hearing. Without a post conviction hearing, there is simply no fully effective means of uncovering instances of abuse of defendants' rights. Neither the judicially created rules relying on the Rule 11 record nor the new procedures for summary disposition of claims can be relied upon to separate meritorious claims from the large number of frivolous ones. While the search for some fully effective screening device goes on, the avenues of post conviction relief for those who plead guilty must remain open.

which the defendant personally participated. See note 62 supra. The opposite might be true, for example, of attacks that focus on the effectiveness of the defendant's counsel. See, e.g., Dukes v. Warden, 406 U.S. 250 (1972) (claim of attorney's conflict of interest).

95. In Townsend v. Sain, 372 U.S. 293, 322 (1963), the Court stressed the importance of allowing testimonial evidence to be introduced. "Where an unresolved factual dispute exists, demeanor evidence is a significant factor in adjudging credibility. And questions of credibility, of course, are basic to resolution of conflicts in testimony. . . . [T]he petitioner, and the State, must be given the opportunity to present . . . testimonial ... evidence relevant to the disputed issues." See United States v. Hayman, 342 U.S. 205, 219-23 (1952) (interpreting $\S 2255$ to require petitioner's presence at hearing when there are substantial issues of fact as to events in which he participated).

In Blackledge v. Allison, 97 S. Ct. 1621, 1633 n.25 (1977), the Court suggested that "[t]here may be cases" in which documentary evidence would prove so overwhelming as to eliminate the need for an evidentiary hearing. However, the Court apparently viewed this as a narrow exception to the general rule, noting that " [w] is one of credibility, resolution on the basis of affidavits can rarely be conclusive . . . " Id. (quoting Raines v. United States, 423 F.2d 526, 530 (4th Gir. 1970)).

96. See p. 1407 supra.

97. See note 27 supra. 